\title{
MANAJEMEN LITERATUR KELABU SEBAGAI PENDUKUNG PENELITIAN DAN PENULISAN KARYA ILMIAH
}

\author{
Endang Ernawati ${ }^{1}$
}

\begin{abstract}
Article explores the role of grey literature in supporting research and the writing of scientific articles in Indonesia. The discussion covers introduction of grey literature terminology, forms, causes, sources, level of confidentiality, users' view, and its development. It is concluded that the grey literature have not been well managed by its institutions; The Indonesia government has paid much attention to the collection, management, and documentation of grey literature; Internet development help the dissemination of grey litearature information in which users can easily access through the website; And the publication of local e-Content in some universities are still in the process of development due to the copy right and facilities problems.
\end{abstract}

Keywords: literature management, grey literature ABSTRAK
Artikel membahas peran literatur kelabu dalam menunjang penelitian dan
penulisan artikel ilmiah di Indonesia. Lingkup bahasan adalah pengenalan, manajemen,
dan pengembangan literatur kelabu, meliputi sejarah, terminologi terkait, sumber,
tingkat kerahasiaan, pandangan pengguna, dan gambaran pengembangan masa depan.
Disimpulkan bahwa literatur kelabu belum dikelola dengan baik oleh masing-masing
institusi pemroduksinya; Pemerintah RI telah menaruh perhatian besar terhadap
manajemen dan dokumentasi literatur kelabu; Perkembangan internet ternyata
membantu penyebaran literatur kelabu karena pengguna dapat mengakses lewat web
sedangkan penulis literatur kelabu dengan cepat dapat mengupload informasinya ke web
tanpa editing yang cermat seperti dalam penerbitan tercetak; Publikasi koleksi lokal di
beberapa universitas masih tetap diusahakan dengan kendala hak cipta dan sarana..
Kata kunci: manajemen literatur, literatur kelabu

${ }^{1}$ Library Manager, Universitas Bina Nusantara

Ketua Forum Perpustakaan Perguruan Tinggi Indonesia ( FPPTI) - DKI

Dosen Universitas Bina Nusantara 


\section{PENDAHULUAN}

Kegiatan penelitian dan penulisan karya ilmiah meningkat seiring dengan semakin tingginya aktivitas pembelajaran di perguruan tinggi. Hal itu disadari oleh banyak pengajar karena kegiatan mengajar memang memerlukan penelitian dengan berbagai tujuan, misalnya untuk mengevaluasi pemahaman materi yang diajarkan, mengetahui hubungan materi ajar dengan perkembangan industri di dalam dan luar negeri, dan mancari metodologi pengajaran yang tepat bagi materi ajar tersebut.

Kegiatan penelitian yang nantinya akan menghasilkan tulisan ilmiah memerlukan dukungan literatur, seperti buku (monografi), artikel jurnal ilmiah, majalah, koran, tesis, disertasi, laporan penelitian, direktori, paten, standar, dan berbagai artikel di internet. Di era informasi ini, literatur dikemas tidak hanya dalam bentuk tercetak tetapi juga dalam bentuk mikro, magnetik, dan kebanyakan elektronik. Walaupun keberadaan literatur telah beragam dan jumlahnya terus meningkat, ternyata sumber informasi ini belum semua dapat dipublikasikan karena berbagai kendala. Jenis literatur yang belum dipublikasikan, banyak diminati, dan sulit untuk diperoleh ini adalah literatur kelabu (grey literature).

Literatur kelabu banyak dihasilkan oleh universitas, institusi pemerintah, maupun swasta yang belum dikelola secara baik. Padahal, banyak sekali kegiatan resmi pemerintah dan swasta, seperti pembuatan kebijakan, pengembangan penelitian, produk, pemasaran, dan lain-lain yang memerlukan sumber literatur kelabu. Begitu pula, Perguruan Tinggi Negeri (PTN) dan Perguruan Tinggi Swasta (PTS) harus selalu mengembangkan bahan ajar, penelitian, dan bahkan kebijakan yang dapat bersumber dan sekaligus menghasilkan literatur kelabu, seperti skripsi, tesis, disertasi, pidato rektor, kebijakan universitas, dan lain-lain.

Literatur kelabu merupakan literatur yang bersifat semipublished, sulit diakses, lebih-lebih bila akan dilacak sumbernya. Kebanyakan literatur itu berisi data informasi penting yang tidak dipublikasikan secara meluas. Berbagai institusi pemerintah maupun non-pemerintah, sekolah tinggi, PTN, PTS, dan perusahaan pemerintah maupun swasta merupakan penghasil utama literatur kelabu. Sesuai dengan sebutan nama warnanya (abuabu $=$ grey), jenis literatur itu memang sulit untuk diakses. Harus ada upaya untuk mengubah sebutan warna kelabu menjadi putih yang berarti literatur kelabu tersebut dibuat menjadi jelas keberadaan dan cara aksesnya.

Berdasarkan kesulitan dalam mengakses literatur kelabu, artikel bertujuan menguraikan state of the art, produsen, dan penyebab keberadaan literatur kelabu; Menguraikan pemanfaatan, pengembangan, dan kebijakan pemerintah berkenaan dengan semakin meningkatnya literatur kelabu tersebut; Menjelaskan konsep manajemen literatur kelabu sehingga lebih mudah diakses untuk pengembangan penelitian dan penulisan ilmiah. 
Metodologi studi, yaitu pengumpulan data dilakukan dengan studi literatur, hasil seminar, dokumen pemerintah, dan digabungkan dengan studi lapangan, yaitu melihat praktik manajemen literatur kelabu di beberapa universitas.

\section{PEMBAHASAN}

\section{Pengertian Literatur Kelabu}

Prytherk (1995) mendefinisikan literatur kelabu sebagai: Semi published materials, for example reports, internal documents, theses, etc., not formaly published or available commercially, and consequently difficult to trace bibliographically.

Definisi itu menggambarkan secara tepat istilah literatur kelabu. Dikatakan bahwa literatur kelabu tidak dipublikasikan secara besar-besaran sehingga sulit dilacak secara bibliografis. Untuk lebih memahami arti literatur kelabu, terdapat beberapa pengertian sebagai berikut. British Library menyebutkan bahwa literatur kelabu adalah dokumen yang tidak terjual bebas sehingga sangat sulit untuk diidentifikasikan dan diperoleh. AFNOR (Association Francaise de Normalisation) menggambarkan literatur kelabu sebagai dokumen yang diketik atau dicetak yang diproduksi untuk kalangan terbatas, di luar jalur penerbitan resmi maupun sistem penyebaran yang berlaku. Literatur kelabu juga mempunyai keterbatasan data bibliografi. Simpulannya, literatur kelabu adalah bentuk dokumen/literatur yang dicetak, diterbitkan, dan disebarluaskan secara terbatas. Biasanya, kodifikasi bibliografi dan penyuntingannya tidak dilakukan secara benar sehingga sulit untuk diakses apalagi untuk memperoleh literatur pendukung tulisan tersebut. Simpulan itu mengakibatkan dua masalah sebagai berikut: Bagaimana usaha untuk mengumpulkan literatur kelabu? Bagaimana menentukan tingkat "kerahasiaan" literatur kelabu tersebut.

\section{Bentuk Literatur Kelabu}

Bentuk dokumen literatur kelabu yang sering dijumpai sebagai berikut: Prosiding konferensi, seminar, lokakarya; Skripsi, tesis, dan disertasi; Laporan tahunan; Laporan perkembangan (Progress Report); Interim Report; Data sheet, manual; Goverment Publication.

Karya ilmiah merupakan luaran kegiatan penelitian dan pengembangan yang membutuhkan dukungan data dan informasi dari literatur kelabu, dalam arti karya ilmiah lain yang tidak dipublikasikan secara komersial. Dukungan informasi tersebut diperlukan untuk memaparkan masalah dan pemecahan masalah yang menggunakan metode ilmiah tertentu sehingga diharapkan hasil atau simpulannya memberikan sesuatu yang baru dan berharga bagi dunia ilmu pengetahuan. Jelaslah, penyusunan karya ilmiah membutuhkan akumulasi dan proses repackaging informasi yang menghasilkan informasi baru. 
Peranan literatur kelabu dalam mendukung analisis karya ilmiah tersebut sehingga menjadi lebih berbobot dibandingkan dengan yang lain karena adanya informasi tambahan yang sulit diperoleh, yaitu literatur kelabu.

\section{Penyebab Munculnya Literatur Kelabu}

Rifai (1995) menyebutkan faktor utama penyebab terbentuknya literatur kelabu sebagai berikut. Pertama, ketidakmapanan tradisi menerbitkan. Banyak penulis merasakan sulit dan lamanya proses mempersiapkan naskah sehingga layak terbit apabila mereka mengirim naskah ke penerbit. Kebanyakan penulis enggan melalui proses itu karena malas mengubah naskah mereka sesuai dengan saran pakar yang meneliti isi dan penyunting yang mengoreksi bahasa dan format naskah. Dengan demikian, mereka lebih suka membiarkan karya mereka apa adanya di universitas atau di institusi sehingga sulit diakses.

Literatur kelabu banyak dijumpai di lingkungan biro penelitian dan pengembangan hanya sebagai laporan terketik dengan eksemplar yang terbatas. Format dan isi laporan tidak standar, dengan atau tidak ada penyuntingan, misalnya makalah seminar, proses penelitian di laboratorium, notulen rapat kerja, laporan perjalanan, berbagai surat keputusan, sambutan, kumulasi data mentah, draft buku, petunjuk kerja, dan bahan ajar.

Kedua, kurangnya tekanan lingkungan untuk membudayakan terbitan sebagai hasil akhir kegiatan, terutama kegiatan penelitian. Komunikasi lisan adalah budaya yang paling sering dilakukan oleh banyak orang di Indonesia, baik dari tingkat keluarga yang banyak dilakukan dengan memberikan cerita kepada anak menjelang tidur, memberi nasehat, dan lain-lain. Tanpa disadari, hal itu sebagai faktor pemicu tumbuhnya literatur kelabu.

Pendokumentasian hasil pertemuan ilmiah juga menghasilkan literatur kelabu. Berbagai pertemuan ilmiah banyak menghasilkan makalah dan sambutan yang dibacakan di hadapan peserta kegiatan ilmiah. Pihak penyelenggara lebih senang apabila kumpulan makalah tersebut segera diterbitkan menjadi suatu prosiding, entah untuk dijual atau dikirimkan pada peserta pertemuan tersebut. Akibatnya, makalah tersebut tidak disunting sebagaimana layaknya pengolahan naskah. Misalnya, penyusunan prosiding hanya mengurutkan makalah sesuai dengan jadwal pertemuan, urutan sambutan penyelenggara, hasil diskusi, daftar peserta, rekomendasi (kalau ada), dan beberapa foto. Kebanyakan penyunting atau redaksi yang terpampang namanya tidak sempat berfungsi dalam mengelola kemapanan penerbitan..Penyebaran prosiding tersebut juga tidak ditangani secara cermat sehingga keberadaannya sulit dilacak oleh kalangan ilmiah yang akan mempergunakan informasi di dalam prosiding tersebut untuk mendukung penelitian dan penulisan ilmiah. Kesulitan pelacakan tersebut menyebabkan prosiding tersebut termasuk literatur kelabu. 
Kemajuan fasilitas telekomunikasi dan komputer mikro menyebabkan semakin beragamnya terbitan elektronik, misalnya KompasNet, GatraNet. Media elektronik tersebut dapat dinikmati oleh sebagian besar ilmuwan dengan fasilitas internet. Konsekuensinya, penyediaan berita secara cepat menyebabkan munculnya literatur berkategori kelabu karena persyaratan efisiensi dan ketepatan keberkalaan yang dikejar oleh teknologi. Jadi, naskah atau berita tersebut tidak disunting dengan baik, format tidak teratur/standar, tidak didaftarkan pada sistem penerbitan nasional serta kodifikasi yang tidak jelas.

\section{Sumber Kepustakaan Kelabu}

Sumber kepustakaan kelabu berasal dari lembaga berikut. Pertama, lembaga penelitian dan pengembangan, dengan luaran berupa laporan penelitian, artikel yang tidak dipublikasikan, proposal penelitian, komersialisasi hasil penelitian, prosiding seminar dan pertemuan ilmiah lain. Kedua, perguruan tinggi dan lembaga pendidikan, seperti bahan ajar, notulen rapat, buku teks dosen lokal, skripsi, tesis, disertasi, pidato rektor, pidato pengukuhan. Ketiga, pertemuan ilmiah: prosiding, notulen. Keempat, pemerintah: dokumen pemerintah. Kelima, badan pemerintah dan swasta: laporan tahunan, laporan teknis, program komputer buatan lokal.

Secara jelas, keberadaan literatur kelabu pada beberapa institusi sebagai berikut.

Pertama, Lembaga Penelitian dan Pengembangan. Indonesia banyak melakukan kegiatan penelitian yang menghasilkan produk berupa barang, jasa, atau teori yang berdampak pada kemajuan ilmu pengetahuan dan teknologi di Indonesia. Namun, harus diakui bahwa masih banyak hasil penelitian yang dihasilkan tidak sesuai standar karena kegiatan penelitian baru dalam taraf memotivasi peneliti atau dosen untuk melakukan kegiatan tersebut sehingga banyak dijumpai laporan asal jadi, tanpa analisis dan sintesis tajam, dan simpulan lengkap. Format laporan tersebut biasanya tidak mengacu pada standar penulisan laporan ilmiah yang benar dan penggandaannya terbatas karena hanya sekadar sebagai pertanggungjawaban projek yang mendanai penelitian tersebut. Haruslah diketahui dan disadari bahwa laporan penelitian tersebut sangat diperlukan tetapi amatlah disayangkan bahwa laporan yang tentu berguna bagi pengembangan penelitian selanjutnya tidak dapat diketahui secara luas kandungan pengetahuannya. Terlebih lagi, apabila projek yang baru telah datang dan penelitian tersebut tidak ada lanjutannya maka isi informasi yang berguna tersebut dapat hilang. Simpulannya, semakin lama akan semakin banyak literatur kelabu yang bertumpuk di lembaga litbang sehingg diperlukan manajemen khusus untuk menangani literatur kelabu ini.

Kedua, Perguruan Tinggi dan Lembaga Pendidikan Tinggi Lain. Jenis literatur kelabu yang banyak dijumpai di Perguruan Tinggi (PT) adalah skripsi, tesis, disertasi, laporan teknis, dan bahan ajar. Tingkat kerahasiaan dokumen itu tergantung pada kebijakan PT masing-masing. Jadi, masing-masing PT dapat mengategorikan literatur kelabu ini sebagai dokumen umum, terbatas, atau rahasia. Cara mengakses dokumen 
tersebut juga beragam, ada yang memakai sistem akses terbuka tetapi ada pula yang terbatas dan memakai akses tertutup. Terbitan lokal (inhouse publication) yang dihasilkan oleh perusahaan, ikatan profesi, partai politik, dan gabungan perdagangan (trade unions) adalah informasi statistik maupun perjanjian ekonomi. Di lain pihak, surat-menyurat, rancangan dan pengembangan organisasi, leaflets, dan perjanjian adalah produk literatur kelabu yang dihasilkan oleh suatu perusahaan.

Alasan utama mengapa pemroduksi literatur kelabu (baik organisasi ataupun perseorangan) tidak menerbitkan dokumen tersebut secara resmi adalah seperti berikut. Pertama, lamanya waktu pemrosesan naskah. Waktu yang diperlukan dari naskah masuk ke meja redaksi sampai menjadi artikel atau buku yang diterbitkan akan memakan waktu lama. Sebagai gambaran, berkala ilmiah memerlukan waktu 6--12 bulan untuk memproses artikel hingga majalah ilmiah tersebut diterbitkan sedangkan majalah ilmiah populer memerlukan waktu 3 bulan. Hal itu disebabkan oleh usaha dewan redaksi untuk mempertahankan kebenaran isi tulisan tersebut, misalnya dengan jasa mitra bestari (peer group). Penyuntingan naskah dari segi kebahasaan, format, serta pendokumentasian naskah (pemberian abstrak dan indeks) agar mudah diakses juga memerlukan waktu.

Kedua, keberkalaan terbitan. Terbitan dalam bentuk jurnal atau majalah akan diterbitkan secara berkala, misalnya ada yang diterbitkan secara tahunan, tengah tahunan, kuartalan, dan triwulanan. Waktu terbit ditentukan berdasarkan kesiapan mengumpulkan dan mempersiapkan naskah hingga layak terbit. Penulis artikel mengirimkan naskah dengan tujuan utama untuk keperluan angka kredit untuk jabatan fungsional mereka dan imbalan honor. Biasanya penulis itu telah antre lama sehingga banyak yang tidak sabar dan memutuskan naskah tidak jadi diterbitkan sehingga menjadi literatur kelabu.

Ketiga, pemakai yang terbatas. Penulis literatur kelabu mengira bahwa laporan/hasil kerjanya hanya menarik dan berguna untuk kalangan tertentu saja sehingga mereka enggan menerbitkannya. Keempat, biaya cetak yang tinggi. Biaya penggandaan berupa cetak masih mahal dibandingkan fotokopi sehingga mereka memutuskan hanya digandakan sesuai dengan keperluan institusi saja. Debachese (1995) menyebutkan bahwa literatur kelabu banyak ditemukan di negara yang sedang berkembang, contohnya Afrika. Di negara tersebut banyak ditemukan penelitian di bidang kesehatan, gizi, dan pertanian yang diterbitkan oleh pusat penelitian dan organisasi sosial yang ingin menerbitkan hasil penelitian tersebut secara murah, dalam arti kualitas kertas, penjilidan, format, dan penyuntingan yang tidak teliti. Biasanya terbitan murah itu tidak disertai acuan bibliografi yang lengkap sehingga sulit dilacak dan digunakan sebagai dasar penelitian. Walaupun keadaannya demikian, literatur kelabu sering menyajikan informasi yang bernilai tinggi karena faktor berikut: Informasi yang dihasilkan biasanya asli dan merupakan hasil penelitian yang sangat spesisfik; Dan informasi yang terbaru (current). 


\section{Standar Format}

Standar Nasional Indonesia (SNI) belum mengarah khusus untuk membakukan format literatur kelabu. Apabila perkembangan SNI memerlukan waktu lama standar lokal PT untuk penulisan tugas akhir misalnya skripsi S1, tesis S2, dan disertasi S3 dapat diterapkan. Begitu pula standar penerbitan prosiding dan laporan penelitian dari Litbang Departemen, nondepartemen, maupun PT. Usul keseragaman dan metode pengaksesan dilakukan oleh PDI-LIPI dengan diberlakukannya pemuatan lembar data bibliografi bagi setiap terbitannya. Lembar data berfungsi untuk mempermudah akses dan melengkapi informasi terbitan tersebut. Contohnya sebagai berikut.

\section{LEMBAR DATA BIBLIOGRAFI TERBITAN}

\begin{tabular}{|c|c|}
\hline $\begin{array}{l}\text { Judul terbitan } \\
\text { Sari Laporan Penelitian dan Survei }\end{array}$ & Klasifikasi DDC : 016.6 \\
\hline $\begin{array}{l}\text { Penyunting } \\
\text { Kamariah Tambunan } \\
\text { Sarwintyas Prahastuti } \\
\text { R. Nani Rahayu }\end{array}$ & Nomor Terbitan : Jilid 29 \\
\hline $\begin{array}{l}\begin{array}{l}\text { Nama dan } \\
\text { Memperbanyak }\end{array} \text { Alamat } \begin{array}{c}\text { Badan } \\
\text { dan } \\
\text { Menyebarluaskan }\end{array} \\
\text { Terbitan } \\
\text { PDII-LIPI } \\
\text { Jl. Jend. Gatot Subroto 10, Jakarta } 12710 \\
\text { P.O Box 4298, Jakarta } \\
\text { Telp. 5733465, 5250719 }\end{array}$ & Jenis Terbitan : Bibliografi \\
\hline $\begin{array}{l}\text { Sponsor dan Nomor Kontrak } \\
\text { PDII-LIPI }\end{array}$ & Edisi/cetakan : Pertama \\
\hline & Tahun terbitan : 2001 \\
\hline & Jumlah halaman : vi + 185 \\
\hline & Jumlah terbitan : 300 eksemplar \\
\hline $\begin{array}{l}\text { Sari (Abstract) } \\
\text { Sari Laporan memuat } 249 \text { sari ( abstrak) } \\
\text { terutama terbitan } 1998 \text { dan sebelumnya. Sari } \\
\text { ini disusun menurut kelompok ilmu-ilmu } \\
\text { sosial, ilmu-ilmu murni, dan ilmu-ilmu terapan. }\end{array}$ & $\begin{array}{l}\text { Nomor mata anggaran atau nama } \\
\text { proyek/kegiatan } \\
\text { Jaringan Informasi Ilmiah Nasional } \\
\text { Tahun Anggaran : } 2001 \\
\text { Kode proyek : } 16.601 .11020042 .02 .001 \\
\end{array}$ \\
\hline Kolom Catatan Penerima Terbitan & $\begin{array}{l}\text { Penyebaran terbitan : bebas } \\
\text { Izin mengutip : Bebas dengan } \\
\text { menyebut sumber. } \\
\text { Harga : - } \\
\text { Penyalur : PDII-LIPI }\end{array}$ \\
\hline
\end{tabular}

(Sumber: Sari Laporan Penelitian dan Survei Jilid 29, 2001) 


\section{Tingkat Kerahasiaan Literatur Kelabu}

Secara umum, tingkat kerahasiaan literatur kelabu terbagi tiga, yaitu rahasia, terbatas, dan umum. Selain penulis literatur kelabu sendiri dan lembaga yang memproduksi literatur kelabu, tingkat kerahasiaan itu masih perlu dikonsultasikan dengan pihak yang berwenang di bidang pemerintah, misalnya Dirjen HKI Departemen Kehakiman.

Parameter yang diacu untuk meningkatkan tingkat kerahasiaan literatur kelabu adalah sebagai berikut. Pertama, Hankam. Hankam dapat dijadikan acuan penentu tingkat kerahasiaan dari segi militer dan politik, misalnya peta kekayaan tambang di Indonesia. Peta tambang itu dapat dikategorikan "terbatas" oleh lembaga penelitian dan pengembangan yang membiayai projek tersebut. Akan tetapi, dokumen tersebut dapat berstatus "rahasia" setelah dikonfirmasikan dengan pihak Hankam.

Kedua, pendekatan ilmu pengetahuan (scientific approach). Hal itu dapat dilakukan antarlembaga penelitian yang sejenis untuk menentukan tingkat kerahasiaan literatur kelabu tersebut. Ketiga, pendapatan kekayaan negara (prosperity approach). Tingkat kerahasiaan literatur kelabu ditentukan oleh tinjauan dari segi ekonomi, teknologi, rekayasa, sosial, dan budaya.

\section{Pandangan Pengguna Literatur Kelabu}

Kebanyakan pemakai beranggapan bahwa literatur kelabu sangat sulit diperoleh dari segi pengaksesan maupun perolehan dokumen. Untuk meningkatkan pemakaian literatur kelabu, harus ada sinergi antara pemakai dan pustakawan. Keduanya harus proaktif untuk memperoleh dokumen tersebut. Perlu juga adanya "keterbukaan" dari pihak produsen literatur kelabu untuk memberikan akses dan kemungkinan perolehan materi yang tingkat kerahasiannya bersifat umum, terbatas, dan rahasia tersebut.

Berdasarkan manfaat literatur kelabu, perlu adanya imbauan kepada penulis literatur kelabu untuk meningkatkan kualitas tulisan dan mencari hubungan dengan penerbit agar tulisan mereka dapat diterbitkan, atau paling tidak menerbitkan dalam website pribadi setelah dilakukan penyuntingan yang baik. Demikian pula, pihak perpustakaan dan dokumentalis diharapkan mampu memberi kemudahan akses terhadap dokumen tersebut bagi kalangan terbatas atau masyarakat luas.

Upaya peningkatan akses literatur kelabu melalui proses penerbitan akan berdampak positif pada hal berikut: Tumbuhnya kelompok spesialis yang rajin mempublikasikan tulisan mereka; Berkembangnya kegiatan penelitan; Meningkatkan kualitas peneliti; Meningkatkan fungsi litbang dengan publikasi penelitian yang dapat diakses dengan mudah; Berkembangnya basis data dan pengumpulan laporan di tingkat institusi; Menggalakkan organisasi profesi agar mampu berperan di dalam menumbuhkan iklim ilmiah. 


\title{
Penambahan Nilai terhadap Literatur Kelabu di Masa Mendatang
}

Pertumbuhan literatur kelabu memang tidak dapat dibendung dan kesadaran pengguna untuk mendapatkannya semakin tinggi guna mendukung penelitian dan penyusunan bahan ajar. Seorang dosen atau peneliti akan merasa lebih yakin apabila dapat memperoleh data atau informasi dari literatur kelabu, yaitu jenis informasi yang tidak dapat diperoleh secara umum di perpustakaan sehingga informasi tersebut menjadi nilai tambah bagi bahan ajar, laporan, atau karya ilmiah yang dihasilkannya. Dengan bersumber literatur kelabu, seorang dosen atau peneliti akan dianggap lebih tahu dari yang lainnya sehingga peranan literatur kelabu secara strategis akan mendukung profesionalisme mereka.

Agar pemakaian literatur kelabu meningkat, diperlukan seperangkat instrumen sehingga data dan informasi yang tersedia dapat digunakan secara maksimal. Pada beberapa negara di Eropa dan Amerika, literatur kelabu telah ditangani secara profesional dan dapat dijadikan komoditi. Di Indonesia dan negara berkembang lainnya, literatur kelabu belum banyak disebarkan dan dipublikasikan, bahkan pengelolaannya juga masih belum tertata baik. Akibatnya, mungkin terjadi banyak orang yang menjadi tenar akibat membaca atau mengembangkan literatur kelabu dibandingkan dengan peneliti atau penulisnya sendiri.

Literatur kelabu dibutuhkan sebagai bahan pembuat kebijakan di bidang ilmu pengetahuan dan teknologi. Menteri Negara Riset dan Teknologi dari Kabinet Persatuan Nasional tahun 2000, Dr. A.S. Hikam, menaruh perhatian yang sangat besar terhadap pengelolaan literatur kelabu ini. Dalam Keputusan Nomor 44/M/Kp/VII/200, beliau mengimbau penyerahan literatur kelabu kepada Kantor Menristek dan PDII-LIPI dengan Surat Keputusan berikut.

\author{
MENTERI NEGARA RISET DAN TEKNOLOGI \\ REPUBLIK INDONESIA \\ KEPUTUSAN MENTERI NEGARA RISET DAN TEKNOLOGI \\ Nomor : 44/M/Kp/VII/2000 \\ Tentang \\ PENYAMPAIAN LITERATUR KELABU (GREY LITERATURE) YANG \\ BERKAITAN DENGAN ILMU PENGETAHUAN DAN TEKNOLOGI
}

MENTERI NEGARA RISET DAN TEKNOLOGI 


\section{Menimbang}

1. bahwa dalam rangka pembuatan kebijakan pembangunan ilmu pengetahuan dan teknologi diperlukan literatur kelabu (grey literature) yang berkaitan dengan ilmu pengetahuan dan teknologi;

2. bahwa dalam rangka memudahkan pembuat kebijakan dan masyarakat untuk memperoleh dokumen-dokumen tersebut perlu dilakukan pendokumentasian yang secara tertib dan terpadu;

3. bahwa untuk maksud tersebut di atas, perlu ditetapkan keputusan yang mewajibkan semua lembaga pemerintah untuk menyampaikan salinan (copy) literatur kelabu (grey literature) yang berkaitan dengan ilmu pengetahuan dan teknologi kepada Kantor Menteri Negara Riset dan Teknologi.

\section{Mengingat}

1. Keputusan Presiden Republik Indonesia Nomor 355/M Tahun 1999.

2. Keputusan Presiden Republik Indonesia Nomor 134 Tahun 1999 tentang Kedudukan, Tugas, Fungsi, Susunan Organisasi, dan Tata Kerja Menteri Negara.

3.

\section{MEMUTUSKAN}

Menetapkan : KEPUTUSAN MENTERI NEGARA RISET DAN TEKNOLOGI TENTANG PENYAMPAIAN LITERATUR KELABU (GREY LITERATURE) YANG BERKAITAN DENGAN ILMU PENGETAHUAN DAN TEKNOLOGI

Pertama

Setiap lembaga pemerintah yang menyimpan dan atau memiliki literatur kelabu (grey literature) berupa laporan penelitian, laporan survey, prosiding, disertasi, tesis, dan dokumen sejenisnya serta publikasi kebijakan pemerintah yang berkaitan dengan ilmu pengetahuan dan teknologi, baik yang berbentuk cetakan maupun dalam bentuk digital (digital file) diwajibkan untuk menyampaikan salinannya kepada Kantor Menteri Negara Riset dan Teknologi.

Kedua

Salinan literatur kelabu (grey literature) tersebut harus disampaikan dalam 3 (tiga) rangkap, dengan ketentuan 1 (satu) rangkap akan dijadikan sebagai bahan analisis dalam pembuatan kebijakan di Kantor Menteri Negara Riset dan Teknologi dan 2 (dua) rangkap lagi akan diserahkan kepada Pusat Dokumentasi dan Informasi Ilmiah (PDII) Lembaga Ilmu Pengetahuan Indonesia untuk didokumentasikan dan diinformasikan ke masyarakat luas. 
Ketiga

Penyampaian salinan literatur kelabu (grey literature) tersebut harus dilakukan paling lambat 3 (tiga) bulan setelah berakhirnya pelaksanaan penelitian atau 3 (tiga) bulan setelah publikasi diterbitkan.

Keempat

Dengan ditetapkannya keputusan ini, literatur kelabu (grey literature) pada setiap lembaga pemerintah akan terdokumentasi secara tertib, terpadu, dan setiap saat dapat diakses untuk dijadikan bahan kajian dalam pembuatan kebijakan pembangunan ilmu pengetahuan dan teknologi selanjutnya.

Kelima

Koordinasi pelaksanaannya dilakukan melalui Deputi Bidang Pendayagunaan dan Pemasyarakatan Iptek, yang akan melaporkannya langsung kepada Menteri Negara Riset dan Teknologi.

Salinan Keputusan ini disampaikan kepada yang terhormat:

1. Presiden Republik Indonesia

2. Wakil Presiden Republik Indonesia

3. Para Menteri Kabinet Persatuan Nasional

4. Ketua Dewan Perwakilan Rakyat

5. Ketua Dewan Pertimbangan Agung

6. Ketua Badan pemeriksa Keuangan

7. Ketua Bappenas.

Ditetapkan di : Jakarta

Pada tanggal : Juli 2000

Menteri Negara Riset dan Teknologi

Republik Indonesia,

Dr. Muhammad A.S. Hikam.M.A.

(Sumber: Http://www.ristek.go.id/referensi/hukum/kp-grey-literature.htm )

Keputusan Menristek itu menyiratkan hal berikut: Literatur kelabu memang betul-betul ada pada setiap instansi pemerintah; Biaya untuk membuat literatur kelabu ini cukup tinggi maka perlu diberdayakan atau diolah kembali untuk kepentingan bersama; Pengelolaan literatur kelabu perlu ditangani dengan baik, terutama dalam segi pendokumentasian dan penyebaran informasi; Untuk mencegah pelanggaran hak cipta, pihak pemerintah cukup jeli dalam menanggulanginya, yaitu harus diserahkan selambatlambatnya 3 bulan setelah penelitian selesai atau 3 bulan setelah publikasi diterbitkan. 


\section{Digitalisasi Literatur Kelabu di Institusi Pemerintah}

Tindak lanjut pendokumentasian literatur kelabu dilakukan oleh Kantor Menteri Negara Riset dan Teknologi bekerja sama dengan PT Astra Graphia, Tbk. Dengan penandatanganan Nota Kesepahaman yang dilaksanakan pada 27 September 2001. Hal yang terkandung dalam nota kesepahaman adalah Program Digitalisasi dan Manajemen Dokumen Bank Data dan Warintek dari Kantor Meneg Ristek adalah sebagai pengembangan pengelolaan literatur kelabu; Program merupakan program nasional yang bertujuan untuk mencerdaskan kehidupan bangsa melalui penerapan manajemen bank data yang berisi informasi yang bermanfaat, seperti disertasi, tesis, laporan riset, dan seterusnya yang nantinya akan dapat diakses masyarakat; Perangkat lunak yang digunakan PT Astra Graphia,Tbk. adalah Xerox Docushare.

\section{Pengembangan Informasi Elektronik}

Dengan semakin banyaknya orang yang mengakses internet, akan semakin banyak pula orang yang bersedia membuat website pribadi untuk memuat tulisan dan gagasan mereka. Dengan cara itu, para penulis tersebut dapat secara cepat menerbitkan karya mereka untuk dikenal secara luas. Penerbitan karya tulis di-web mempunyai dampak positif bagi penulis karena dengan semakin banyaknya orang yang akses, karya mereka akan semakin dikenal, dan otomatis masyarakat akan memprotek karya mereka, seperti aliran copy left yang dikenalkan Onno Purbo.

\section{Manajemen Literatur Kelabu di Perguruan Tinggi}

Banyak Perguruan Tinggi yang telah menata literatur kelabu mereka, terutama skripsi, tesis, dan laporan penelitian dalam bentuk berikut. Pertama, layanan onsite, yaitu pengguna dapat meminjam koleksi tersebut di tempat, memfotokopi halaman yang diperlukan dengan seijin perpustakaan. Alat pencarinya adalah katalog. Kedua, digitalisasi literatur kelabu, atau juga disebut Local e-Content. Skripsi dan tesis dibongkar untuk di-scan halamannya kemudian hasilnya diedit yang dapat diakses secara lokal atau di-upload ke website. Cara pencarian dengan database bibliografi dari titik akses kata kunci judul atau penulis.

\section{Hak Cipta}

Publikasi skripsi dan tesis melalui website masih menimbulkan pro dan kontra di kalangan perguruan tinggi. Hal yang mereka takutkan adalah menyuburnya plagiarism terhadap karya ilmiah yang diterbitkan tersebut, begitu pula dengan hak cipta penulisnya. Jika diamati, salah satu sebab tumbuhnya plagiarism adalah terbatasnya akses terhadap skripsi dan tesis, misalnya literatur tersebut hanya dapat dibaca onsite tetapi apabila karya cipta tersebut dapat diakses secara lebih luas maka praktik plagiarism dapat dikurangi atau bahkan hilang karena orang segan menyontek karya orang lain yang telah diketahui oleh masyarakat akademis secara meluas. Sebagai kompensasi, mungkin kebiasaan 
mengutip dengan benar akan tumbuh subur dan inilah hakikat dari pengembangan ilmu pengetahuan, yaitu mengembangkan atau memberi nilai lebih berdasarkan sesuatu yang telah diteliti oleh orang/pakar lain.

Manfaat lain disebarluaskannya local e-Content ini adalah pencari informasi, terutama mahasiswa dan dosen, akan tahu perkembangan ilmu pengetahuan berdasarkan hasil skripsi, tesis, dan disertasi yang mereka lihat melalui website. Para dosen akan tahu judul apa saja yang telah dijadikan skripsi sehingga duplikasi judul dapat dikurangi. Begitu pula, hak mahasiswa agar dapat mengakses beragam informasi guna menunjang proses belajar mereka dapat dipenuhi. Dalam praktiknya, tampilan database full-text ini masih terbatas untuk kalangan universitas sendiri, bagi pengguna luar mereka menampilkan database bibliografi beserta abstrak, dan hal ini cukup untuk mendeteksi perkembangan ilmu pengetahuan melalui karya tulis mahasiswa.

Saat ini, beberapa perguruan tinggi dan institusi di Indonesia sedang bekerja sama untuk membuat jaringan database local e-Content yang disebut Jaringan Informasi Digital Indonesia (JIDI) dengan koordinator Perpustakaan Pusat Universitas Indonesia. Konsep kerja samanya adalah pengguna dapat mengakses literatur dari kata kunci, setelah ketemu literatur tersebut berada di universitas atau institusi mana maka diberlakukan cara akses atau peminjaman sesuai dengan aturan setempat. Apabila sudah beroperasi, jaringan informasi digital ini tentu amat bermanfaat bagi kalangan akademisi di Indonesia.

Mempublikasikan skripsi dan tesis melalui website apakah melanggar hak cipta mahasiswa? Hal itu dapat diterangkan sebagai berikut. Dalam penulisan skripsi atau tesis, mahasiswa mempunyai hak exclusive, yaitu hak untuk mempublikasikan dan mengembangkan karya ciptanya dengan bekerja sama dengan berbagai pihak tetapi universitas juga mempunyai hak non-exclusive, yaitu hak untuk menyimpan dan mempublikasikan untuk kepentingan akademik, bukan bisnis. Apabila karya mahasiswa itu diperbolehkan difotokopi maka mereka akan mendapatkan kompensasi yang ditentukan oleh universitas setempat, biasanya 15 - 20\% dari biaya fotokopi.

\section{PENUTUP}

Dari uraian pengertian, sumber, pembagian, manajemen, dan kebijakan pemerintah tentang literatur kelabu dapat disimpulkan hal berikut. Pertama, literatur kelabu sebagai sumber informasi terkini, spesifik, dan penting belum dapat dikelola dengan baik secara nasional karena berbagai kendala, di antaranya karya ilmiah itu masih tertumpuk hanya sebagai luaran administratif kegiatan projek, kebijakan institusi, dan belum adanya undang-undang dan peraturan tentang literatur kelabu tersebut. 
Kedua, keputusan Menristek tentang wajib serah literatur kelabu yang berkaitan dengan iptek serta kerja sama dengan PT Astra Graphia untuk mendokumentasikan literatur kelabu merupakan usaha pemerintah agar jenis literatur ini dapat diakses masyarakat luas. Ketiga, perkembangan internet memotivasi penulis literatur kelabu untuk membuat web pribadi sehingga kekhawatiran pengguna informasi untuk mengakses literatur kelabu dapat diatasi.

Keempat, dalam mempublikasikan karya tulis mahasiswa, mereka mendapatkan hak exclusive, yaitu untuk menyebarluaskan dan mengembangkan tulisannya sedangkan universitas tempat dia belajar dan berkesempatan menulis karya ilmiah untuk mendapatkan gelar kesarjanaan mendapat hak non-exclusive, yaitu hak untuk menyimpan dan menyebarluaskan karya tulis untuk kepentinganpembelajaran yang bersifat nonbisnis. Kelima, beberapa perguruan tinggi sedang berusaha bekerja sama guna sharing informasi local e-Content yang dimiliki dalam suatu sistem yang terintegrasi. Kerja sama ini bertujuan untuk memperluas akses ke literatur kelabu dan mendeteksi perkembangan ilmu pengetahuan di Indonesia.

\section{DAFTAR PUSTAKA}

James, Jeffrey. "Reconstructing the Digital Divide From the Perspective of a Large, Poor, Developing Country.” Journal of Information Technology. Volume 19 No.1 2004: $172-177$.

Grey Literature in the Asia - Pacific: The National Library's(www.nla.gov.au/nla/staffpaper)

"Grey Literature: An Enormous Amount of Information in Forestry is Available in Informal Publications.” Occasional Paper No.10, retrieved April 26, 2004 from (http:"'www.cifor.cgiar.org/ publications/html/vcc papeer 10/india html)

Rydberg, Jeffrey A. et al. "Knowledge Management in the Perseus Digital Library." Retrieved April 26, 2004 from http:// www.ariadne.ac.uk/issue25/hydberg.conc. 